\title{
Revisiting Kerala's Gulf Connection: Half a Century of Emigration, Remittances and Their Macroeconomic Impact, 1972-2020
}

\author{
K. P. Kannan ${ }^{1}$ - K. S. Hari ${ }^{2}$
}

Accepted: 2 September 2020 / Published online: 19 October 2020

(c) Indian Society of Labour Economics 2020

\begin{abstract}
In the literature on development studies, the state of Kerala in India is known for its high human and social development despite its low-income status. However, there has been a turnaround in its growth performance and has now come to occupy a high rank in terms of per capita income among Indian States. This has been largely through a high growth performance facilitated by significant remittances from abroad. However, there have not been consistent time-series data on annual remittances. This paper is an attempt to fulfil this gap by estimating foreign remittances to Kerala for a period of 47 years that is close to half a century. Using these data, the paper has presented a Modified State Income for Kerala and calculated its impact on consumption and savings. The significance of the sizeable emigration to the labour market situation has also been highlighted. Given the fact that remittances come as household income confined to a small segment of the total households, the impact of annual remittances on income and consumption inequality has also been highlighted. The results show an increasing trend in inequality. Despite a high growth performance aided by remittances, Kerala has not been able to address its longstanding problem of educated unemployment, especially for its women. In this context, the state's inability to take advantage of the enhanced per capita income to maintain its tax-income ratio, let alone enhance it, assumes great significance as an area of concern.
\end{abstract}

Keywords International migration $\cdot$ Remittances $\cdot$ Inequality $\cdot$ Kerala $\cdot$ India

\section{K. P. Kannan}

kannankp123@gmail.com

1 Present Address: Centre for Development Studies, Thiruvananthapuram, Kerala State, India

2 Gokhale Institute of Economics and Politics, Pune, Maharashtra State, India 


\section{Introduction}

During the last decade, India has emerged as the single largest recipient of private remittances from abroad. The state of Kerala has been a star performer in this followed by Punjab and Gujarat. The role of foreign remittances in the economy of the state of Kerala in the form of money sent by its workers is now widely acknowledged. ${ }^{1}$ As of 2020, Kerala emigrants abroad at 2.12 million, who have an identifiable household to report in Kerala, works out to a little more than $6 \%$ of the population but 17 to $18 \%$ of its workforce. Six countries in the Arabian Peninsula, called Gulf countries (Bahrain, Kuwait, Oman, Qatar, Saudi Arabia and the United Arab Emirates), accounted for $96.8 \%$ of the total emigrants in 1998; it came down to $89.4 \%$ in 2018 (Sunny et al. 2020: 21).

However, reliable estimates of the quantum of such remittances over time have been difficult to obtain for a regional economy like Kerala because Balance of Payments Accounts are prepared at the national level. The revival of growth in the Kerala economy since the late $1980 \mathrm{~s},{ }^{2}$ after more than a decade of economic stagnation, brought into prominence the role of remittances. It is in this context that we attempted an estimation of remittances to Kerala for a period of 27 years from 1972-1973 to 1999-2000 and spelled out its importance to the macroeconomy of Kerala (Kannan and Hari 2002). Given the resilience of remittances-despite two wars in the Gulf region and the 2008 global financial crisis-and its continuing influence on the macroeconomy of Kerala, we decided to revisit our earlier paper to construct a long-term series of remittances, from 1972-1973 to 2019-2020, covering a period of 47 years that is close to half a century and to highlight the macroeconomic impact.

The main conclusions of our revisit are: (a) an impressive increase in the number of Kerala emigrants from one lakh in 1981 to 5.3 lakhs by 1990 and 15.30 lakhs by 2000 reaching a peak of 24 lakhs by 2012 and then a decline to 21.22 lakhs by 2019 , (b) an equally impressive increase in total remittances, (c) an increase in per capita remittances despite a recent decline in total emigrants and (d) an impressive increase

\footnotetext{
1 Although Kerala's history of international migration, in any significant sense, can be traced to only about 70 years or so, the migration to Gulf countries since the oil price boom of 1973 became a watershed and constitutes its single largest stream of international migration so far. As such, this provoked a large number of studies on the various socio-economic aspects of migration and its probable impact on certain aspects of the economy. Some of these studies are Gulati and Mody (1983), Nair (1989), Saith (1992), Krishnan (1994) and Issac (1997). The Kerala Migration Survey (KMS) started in 1998 under the leadership of K.C. Zachariah contributed to a measurement of the migration flows along with the socio-economic characteristics and dynamics of the emigrant households through periodic household surveys. Several papers and books were produced based on these surveys. These are summarised in Zachariah et al. (2003), Zachariah and Irudaya Rajan (2001) and Irudaya Rajan and Zachariah (2019).

2 Kerala's remarkable recovery, after a long period of stagnation in income, was highlighted in a study of the growth performance of Indian states by Ahluwalia (2000). In a study of the growth performance of the industrial sector, Subrahmanian and Azeez (2000) underlined the continuing high growth performance of the Kerala economy since the late 1980s. Kannan reported the recovery from the slow growth 'since the late 1980s that marked the beginning of economic liberalisation process in the country' (1998: L-67) but did not pursue this finding further in that study. This was done later in Kannan (2005; revised in 2007).
} 
in consumption and savings making Kerala one of the high-income and consumption states in India. However, a downside of this has been an increase in income inequality. From a public finance point of view, this increase in consumption has not been accompanied by even maintaining the tax-to-state income ratio, let alone increase it, due to a manifest decline in tax collection efficiency.

\section{Our Method}

There have been several attempts to estimate the remittances to Kerala, but they are either limited by methodology or an absence of reliable database and/or limited period of coverage (for details, see Kannan and Hari 2002). Our method is a direct estimate of the remittances to the economy. In the Balance of Payments statistics published by the Reserve Bank of India (RBI), remittances can be identified as credits in current account as 'net private transfers' ${ }^{3}$ and also as 'net NRI deposits' in the capital account. From these figures, we have estimated region-wise remittances to the Indian economy in terms of Middle East countries and other countries.

The method we have adopted to estimate the remittances to the Kerala economy is as follows:

$$
R_{k t}=\left[R_{I}(\mathrm{ME}) * k_{t}\right]+\left[R_{I}(\mathrm{OME}) * k_{t}(a)\right]+\mathrm{NRE}_{k t}+R_{k t}(K),
$$

where $R_{k t}$ is the remittance to Kerala in year $t ; R_{I t}(\mathrm{ME})$ is the remittance to India from the Middle East countries; $k_{t}$ is the share of persons from Kerala in the stock of Indians in the Middle East; $R_{I t}(\mathrm{OME})$ is the remittance to India from countries other than the Middle East; $k_{t}(a)$ is the assumed share of remittance to Kerala from countries other than the Middle East; $\mathrm{NRE}_{k t}$ represents the non-resident external (foreign exchange) deposits in banks located in Kerala; and $R_{k t}(K)$ represents the money equivalent of remittance in kind to Kerala.

The details of the method adopted and the data sources are given in "Appendix". The important aspects of our method are the following. (a) We have been able to generate an year-wise stock of Keralites in Gulf/Middle East countries as well as the rest of the world from the results of the Kerala Migration Surveys (KMS) for seven time points between 1998 and 2018 (see Irudaya Rajan and Zachariah 2019: 29). These figures were used to work out the share of Kerala in the total stock of Indian emigrants that were collected separately. A time series of the stock of Kerala emigrants were constructed for the period 1973 to 2019 through interpolation and extrapolation (for details, see "Appendix"). This share is taken as the share of Kerala out of the total remittances to India. These were worked out separately for the Middle

\footnotetext{
3 The RBI defines net private transfers as 'Private transfers constitute remittances by non-residents for family maintenance, repatriation of savings by Indian resident's abroad and personal gifts and donations to religious and charitable institutions in India. In addition, other components such as import of gold and silver brought in as baggage by returning Indians and local withdrawals were included under private transfer receipts since 1992-1993 and 1996-1997 respectively' (Reserve Bank of India Bulletin, January 2001:28).
} 
East countries and rest of the world since the former accounts for an overwhelming share of Kerala emigrants as well as remittances in the total. (b) We have assigned a share of remittances in kind to total remittances to Kerala. This was $6.18 \%$ of the total remittances during the 1990s obtained from the 1998 survey of Zachariah et al. (2001). For the period up to 1991, we have taken twice this rate since the temptation for bringing electronic and other valuable goods was much greater prior to the liberalisation of the Indian economy. From 1992-1993 to 1999-2000, we applied this rate. The Kerala Migration Surveys of 2003 and 2007 have reported a decline in remittance in kind as a percentage of total remittances, and these have been applied to the period since 2000-2001 (see "Appendix"). (c) Since the data on NRI deposits in banks located in Kerala are published as 'outstanding deposits as on 31 March', we have taken the annual change as the net inflow on this account.

\subsection{Estimates of Remittance Income}

Based on the above method, we have constructed time-series data on foreign remittances to Kerala from 1972-1973 to 2019-2020. The relevant figures are given in Table 1. What comes out clearly from these estimates is that the magnitude of annual foreign remittances to Kerala started acquiring significance (i.e. equivalent to $10 \%$ of the annual state income) by the early 1980s when international labour migration began to acquire momentum. It reached a high of close to $25 \%$ in 2002-2003 followed by a decline before recovering to close to $24 \%$ in 2013-2014. But since then, it has been a decline once again. Since our estimation of remittances depends crucially on the estimation of emigrants, it is important to see the trend. Figure 1 shows that there has been a secular trend till 2013 followed by a slow decline.

The periodic fluctuations in remittances would get smoothened if we take the annual average flows for every 5 years. What this shows is that the decline in remittances in some years is getting more than compensated by increases in remittances in other years within these 5-year blocks. In terms of absolute magnitudes, 5-year average annual remittances ranged from Rs. 536 crores during 1980-1985 and Rs. 10,836 crores during 1995-2000. It jumped to Rs. 75,925 crores during 2010-2015 and Rs. 90,468 crores during 2015-2020. As a percentage of the Net State Domestic Product (NSDP) remittances, equivalence constituted, on an average, around $15 \%$ for the whole 47 -year period. It was around $11 \%$ since the early 1980 s to the early 1990s (till the end of the fixed exchange rate system). Between 1995 and 2015 , it doubled to around $22 \%$. It declined to $14 \%$ equivalent to state income during 2015-2020. ${ }^{4}$ This relative decline in remittance, despite an increase in absolute

\footnotetext{
${ }^{4}$ The Central Statistical Organisation of the Government of India changed the base year of India's GDP calculation from 2004-2005 to 2011-2012 along with a change in methodology of estimation. It gave rise to a debate among economists which is yet to arrive at a consensus (see, for a critical view, Subramaniam 2019 and Nagaraj 2019). It also affected Kerala's NSDP that jumped by 40\% between 2010-2011 and 2011-2012. However, remittances also increased by 30\%, thereby minimising the relative decline from 21.12 to $19.45 \%$ of NSDP in equivalence. However, the remittances continued to grow faster reaching $23.5 \%$ of NSDP by 2013-2014. Since then, it has declined to $13.3 \%$ of NSDP in equivalence. Hence, the change in the estimation of NSDP has not been the main factor in the relative decline of remittances to Kerala.
} 
Table 1 Foreign remittances (REMT) to Kerala (Rs. crores)

\begin{tabular}{|c|c|c|c|c|c|c|}
\hline Years & $\begin{array}{l}\text { Net private } \\
\text { transfers }\end{array}$ & $\begin{array}{l}\text { Net NRI } \\
\text { deposit }\end{array}$ & REMT in kind & $\begin{array}{l}\text { Total remit- } \\
\text { tances }\end{array}$ & NSDP & $\begin{array}{l}\text { REMT } \\
\text { as \% of } \\
\text { NSDP }\end{array}$ \\
\hline 1 & 2 & 3 & 4 & 5 & 6 & 7 \\
\hline $1972-1973$ & 5.77 & 1.7 & 0.84 & 8.31 & 1457 & 0.57 \\
\hline 1973-1974 & 8.00 & 1.4 & 1.20 & 10.6 & 1823 & 0.58 \\
\hline 1974-1975 & 13.47 & 5.9 & 2.64 & 22.01 & 2086 & 1.06 \\
\hline $1975-1976$ & 33.72 & 3.7 & 8.52 & 45.94 & 2228 & 2.06 \\
\hline 1976-1977 & 56.99 & 35 & 16.26 & 108.25 & 2398 & 4.51 \\
\hline 1977-1978 & 92.44 & 44 & 25.24 & 161.68 & 2521 & 6.41 \\
\hline 1978-1979 & 93.36 & 36 & 22.76 & 152.12 & 2754 & 5.52 \\
\hline 1979-1980 & 138.57 & 41 & 37.50 & 217.07 & 3156 & 6.88 \\
\hline 1980-1981 & 244.40 & 48 & 55.84 & 348.24 & 3823 & 9.11 \\
\hline 1981-1982 & 274.22 & 63 & 45.16 & 382.38 & 4050 & 9.44 \\
\hline 1982-1983 & 326.67 & 105 & 48.74 & 480.41 & 4712 & 10.20 \\
\hline 1983-1984 & 380.97 & 187 & 55.72 & 623.69 & 5523 & 11.29 \\
\hline 1984-1985 & 509.36 & 271 & 67.18 & 847.54 & 6141 & 13.8 \\
\hline 1985-1986 & 472.47 & 50 & 58.84 & 581.31 & 6503 & 8.94 \\
\hline 1986-1987 & 562.11 & 299 & 68.12 & 929.23 & 7354 & 12.64 \\
\hline 1987-1988 & 715.09 & 176 & 81.18 & 972.27 & 8258 & 11.77 \\
\hline 1988-1989 & 608.98 & 215 & 75.58 & 899.56 & 9182 & 9.80 \\
\hline 1989-1990 & 727.89 & 428 & 84.04 & 1239.93 & 10,668 & 11.62 \\
\hline 1990-1991 & 581.24 & 292 & 72.60 & 945.84 & 12,173 & 7.77 \\
\hline 1991-1992 & 1693.22 & 735 & 109.11 & 2537.33 & 15,102 & 16.80 \\
\hline 1992-1993 & 1565.24 & 1460 & 99.09 & 3124.33 & 17,175 & 18.19 \\
\hline 1993-1994 & 2366.30 & 1516 & 146.62 & 4028.92 & 23,401 & 17.22 \\
\hline 1994-1995 & 5212.67 & 871 & 326.67 & 6410.34 & 28,697 & 22.34 \\
\hline 1995-1996 & 5851.76 & 1217 & 365.91 & 7434.67 & 35,087 & 21.19 \\
\hline 1996-1997 & 7446.37 & 2075 & 478.25 & 9999.62 & 40,819 & 24.50 \\
\hline 1997-1998 & 8203.73 & 2557 & 541.30 & $11,302.03$ & 47,924 & 23.58 \\
\hline 1998-1999 & 8145.46 & 2672 & 468.16 & $11,285.62$ & 56,563 & 19.95 \\
\hline 1999-2000 & 8257.14 & 5395 & 505.74 & $14,157.88$ & 62,557 & 22.63 \\
\hline 2000-2001 & 9838.79 & 2707 & 569.58 & $13,115.37$ & 63,813 & 20.55 \\
\hline 2001-2002 & $12,438.14$ & 3103 & 705.57 & $16,246.70$ & 67,963 & 23.91 \\
\hline 2002-2003 & $13,738.33$ & 4162 & 812.68 & $18,713.01$ & 75,860 & 24.67 \\
\hline 2003-2004 & $17,547.73$ & 1404 & 860.41 & $19,812.14$ & 84,734 & 23.38 \\
\hline 2004-2005 & $15,897.00$ & -980 & 677.23 & $15,594.24$ & 104,776 & 14.88 \\
\hline 2005-2006 & $18,103.39$ & 1551 & 341.99 & $19,996.38$ & 120,269 & 16.63 \\
\hline 2006-2007 & $21,592.87$ & 2633 & 421.53 & $24,647.40$ & 135,104 & 18.24 \\
\hline 2007-2008 & $26,127.42$ & -3415 & 395.20 & $23,107.61$ & 153,981 & 15.01 \\
\hline 2008-2009 & $29,086.18$ & 7130 & 630.16 & $36,846.34$ & 180,134 & 20.45 \\
\hline 2009-2010 & $47,405.28$ & -133 & 822.54 & $48,094.82$ & 206,070 & 23.34 \\
\hline 2010-2011 & $47,710.56$ & 804 & 727.72 & $49,242.28$ & 233,177 & 21.12 \\
\hline 2011-2012 & $52,104.17$ & 10,764 & 943.02 & $63,811.19$ & 328,021 & 19.45 \\
\hline
\end{tabular}


Table 1 (continued)

\begin{tabular}{lllllll}
\hline Years & $\begin{array}{l}\text { Net private } \\
\text { transfers }\end{array}$ & $\begin{array}{l}\text { Net NRI } \\
\text { deposit }\end{array}$ & REMT in kind & $\begin{array}{l}\text { Total remit- } \\
\text { tances }\end{array}$ & NSDP & $\begin{array}{l}\text { REMT } \\
\text { as } \% \text { of } \\
\text { NSDP }\end{array}$ \\
\hline $2012-2013$ & $63,501.98$ & 17,736 & 1218.57 & $82,456.55$ & 371,384 & 22.20 \\
$2013-2014$ & $68,941.21$ & 27,693 & 1449.51 & $98,083.72$ & 417,265 & 23.51 \\
$2014-2015$ & $69,038.17$ & 15,720 & 1271.37 & $86,029.55$ & 460,614 & 18.68 \\
$2015-2016$ & $62,872.24$ & 26,006 & 1333.17 & $90,211.42$ & 505,910 & 17.83 \\
$2016-2017$ & $61,122.98$ & 16,740 & 1167.94 & $79,030.93$ & 570,591 & 13.85 \\
$2017-2018$ & $61,447.24$ & 17,595 & 1185.63 & $80,227.87$ & 632,727 & 12.68 \\
$2018-2019$ & $76,157.11$ & 20,111 & 1444.02 & $97,712.13$ & 707,542 & 13.81 \\
$2019-2020$ & $81,479.10$ & 22,122 & 1554.02 & $105,155.22$ & 788,910 & 13.33 \\
Average/year & $18,973.70$ & 4463.62 & 466.68 & $23,904.00$ & $138,187.13$ & 14.75 \\
\hline
\end{tabular}

(1) Figures in brackets indicate NRI deposits as a percentage of total remittances. (2) Net private transfers to Kerala have been worked out on the basis of the methodology given in the text. Column 3 refers to the deposits of non-resident Indians in the banks located in Kerala. These are published in the Economic Review published by Government of Kerala, annually. NSDP refers to Net State Domestic Product, which is collected from CSO Estimates of State Domestic Product (Government of India, Estimates of State Domestic Product, Various Issues)

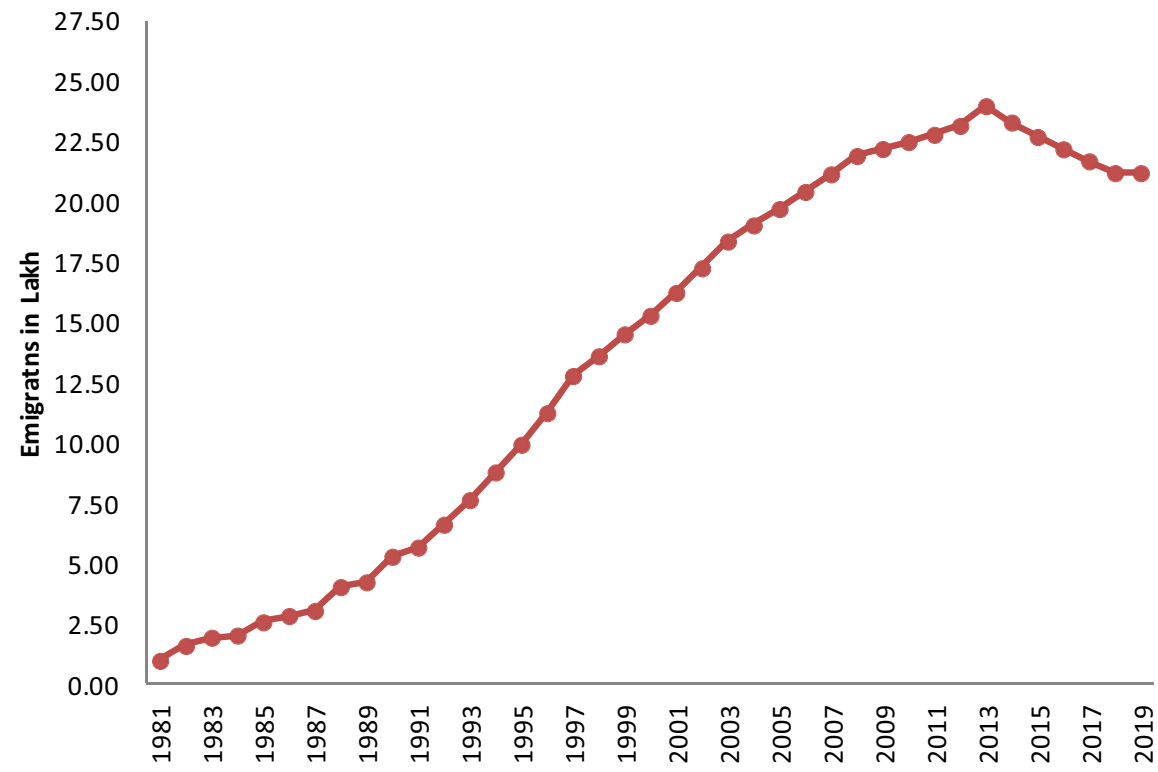

Fig. 1 Total emigrants from Kerala (in lakhs). Source: Based on data in Table 15 given in the Appendix 
levels, is due to a much higher growth in annual state income than in rupee remittances (Table 8). ${ }^{5}$ This is an interesting development about which we comment briefly in the last section.

\subsection{Long-Term Increase in the Flow of Remittances Despite Some Fluctuations}

Smoothening the annual fluctuations in remittances by taking the averages for 5-year blocks, we summarise the overall picture in Table 2. First, the remittances increased secularly in both rupee terms and US dollars. Neither the two Gulf Wars nor the 2008 financial crisis seems to have affected the flow of remittances. Remittance relative to state income (NSDP) also increased secularly till the end of the twentieth century but then started declining. Since 2011-2012, there has been a decline in the growth rate of remittances to a significant extent (Table 8). This is partly due to the net decline in Kerala emigration to the extent of 13\% between 2013 and 2019 (Fig. 1). But this has not affected the average annual flow when a block of 5 years is taken. This is also the case when we take the remittances in US dollars (Fig. 2). It is also interesting to note that the per capita per emigrant remittances for Kerala are higher by 25 to $35 \%$ when compared with the all India (columns 7 and 8 in Table 2). We shall comment on the per capita per remittance-receiving household (column 5), later.

The net decline in the number of Kerala emigrants (close to $90 \%$ of whom are concentrated in the Gulf countries) has been the result of changes in both demand and supply factors. From the demand side, there has been an increasing push for absorbing its citizens into the workforce in many Gulf countries in addition to a change in the structure of demand for labour in the Gulf countries in favour of the more educated category.

From the supply side in Kerala, the major factors seem to be the advanced stage of demographic transition leading to a situation of close to a zero rate of growth of population, increasing wage rates of casual male workers and the increasing levels of educational attainments of the younger population.

\subsection{Compositional Changes in Emigrants and the Increase in Per Capita Remittance}

A good part of the increase in remittance per emigrant is due to the depreciation of the Indian rupee. However, since 2008, there has been a real increase in remittance per emigrant measured in dollar terms (Table 2, column 7). We attribute the reasons for this to the compositional changes in the emigrant population in favour of the higher educated. Recent work based on the computation of unit-level data five rounds of the Kerala Migration Survey (KMS) data (see Sunny et al. 2020) has brought out the educational attainments of emigrants, which are summarised

\footnotetext{
5 The higher growth in state income was also largely propelled by earlier remittances through its consumption and investment multipliers. But the lower growth in remittances since 2015 is related to a decline in emigration as well as a lower rate of depreciation of the Indian rupee.
} 


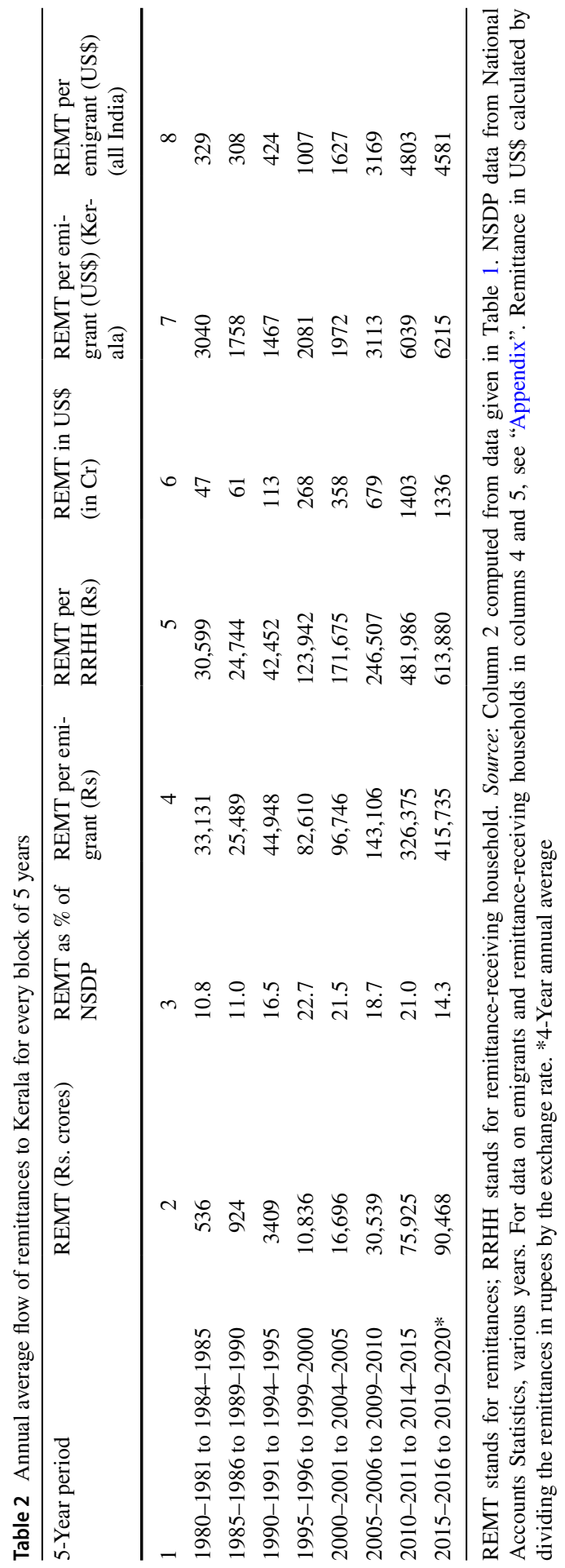


( Base Year 1980-81=100)

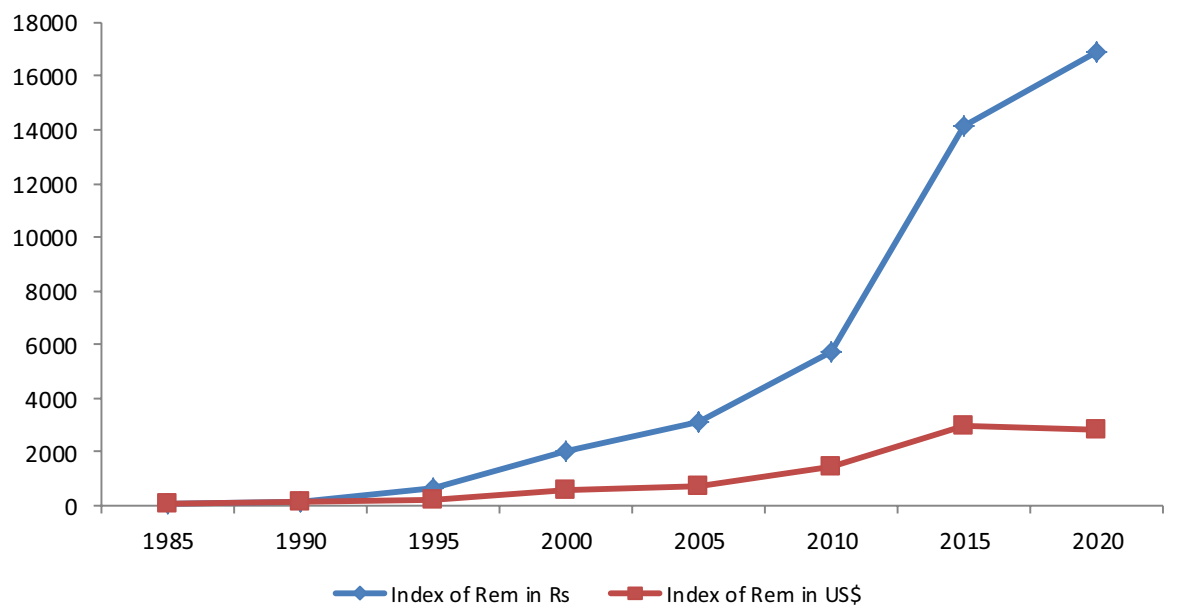

Fig. 2 Index of average annual flow of total remittances in rupees and US dollars based on 5-year averages: 1980-1985 to 2015-2020 (base year 1980-1981=100). Source: Computed on the basis of data in Table 2, Columns 2 and 6

Table 3 Percentage distribution of the educated among the Kerala emigrants

\begin{tabular}{llll}
\hline Years & $\begin{array}{l}\text { Graduates and } \\
\text { above }\end{array}$ & Higher secondary & Secondary \\
\hline 1998 & 3.84 & 12.30 & 39.38 \\
2008 & 15.27 & 22.73 & 40.45 \\
2018 & 30.51 & 29.68 & 30.84 \\
\hline
\end{tabular}

Source: Sunny et al. (2020: 21)

in Table 3. It is quite evident that the educational composition of emigrants has undergone a sharp change within a period of two decades from 1998. By 2008, the share of the higher educated (higher secondary and above) increased from 16.1 to $38 \%$ (2.35 times). The period around 2008 coincides with the start of the rise in remittance per emigrant in US dollars (Table 2, column 7). By 2018, those with higher education - taken as those with at least a higher secondary level-formed as much as $60 \%$. This is reflected in the occupational categorisation of emigrants that has also been reported in the recent study mentioned above. We summarise it in Table 4. Those with secondary education have been referred as 'up to secondary education', and hence, only a part of them could have successfully completed secondary education. Even if half of them is assumed to have a secondary level, then the share of educated increases to $76 \%$. This of course is reflected in the occupational distribution. The less skilled manual labour-oriented jobs in the last two categories in Table 4 which were close to half the emigrant workers in 1998 got reduced to $32 \%$ in 2008 and then to just $19 \%$ by 2018 . The largest group is described as professionals in the private sector, and the self employed could also be included in that category. In terms of wages, government employees would 
Table 4 Percentage distribution of emigrants by occupation in the host countries

\begin{tabular}{lrrr}
\hline Category & 1998 & 2008 & 2018 \\
\hline Government employee & 3.3 & 7.3 & 7.8 \\
Professionals in private sector & 43.8 & 57.0 & 67.4 \\
Self-employed & 4.5 & 3.4 & 5.7 \\
Sub-total & 51.6 & 67.7 & 80.9 \\
Casual labour & 44.4 & 25.0 & 13.4 \\
Other low paid & 3.8 & 7.1 & 5.8 \\
Sub-total & 48.2 & 32.1 & 19.2 \\
Total & 100.0 & 100.0 & 100.0 \\
\hline
\end{tabular}

Note as given by the authors: Professionals in private sector include doctors, nurses, engineers, scientists, professors, lecturers, teachers, accountants, lawyers, architects, designers and newspaper editors. [We assume that this group also includes all kinds of paramedical staff, journalists, IT professionals and office staff with higher education and so on.]. Casual labour includes low-skilled technicians, drafters, salespersons, masons, plumbers, carpenters, waiters, cooks and other helpers. Other low paid includes household maidservants, cleaners, washer men and others. Source: Sunny et al. (2020: 20)

also be close to the private sector professionals of the kind described in Table 4. Such a picture of compositional change in terms of education and occupation suggests that Kerala emigration has undergone a transformation in favour of the higher educated and hence higher earnings than before. This explains the reason for the secular increase in remittance per emigrant since 2008. The remittance per remittance-receiving household (RRHH) based on the proportion of households with current emigration and the proportion of such households actually receiving remittances (see Sunny et al. 2020) tells us about the skewed distribution of the remittance income with implications for income inequality, discussed later.

\section{4 'Windfall' Gain Due to Liberalisation of Exchange Rate}

Kerala benefited substantially as a result of exchange rate liberalisation in 1991 moving from a fixed exchange rate to a floating (though managed) exchange rate system. ${ }^{6}$ This, in our opinion, should be reckoned as the single most gain of Kerala as a result of economic reforms introduced in 1991. We have quantified this gain by estimating the difference between actual exchange rate since 1991 and the expected exchange rate without liberalisation. This may be represented as

$$
G_{r t}=R_{t}\left(r_{a t}-r_{e t}\right)
$$

\footnotetext{
${ }^{6}$ Some extra burden on local banks might have been imposed for remitting old foreign currency accounts.
} 


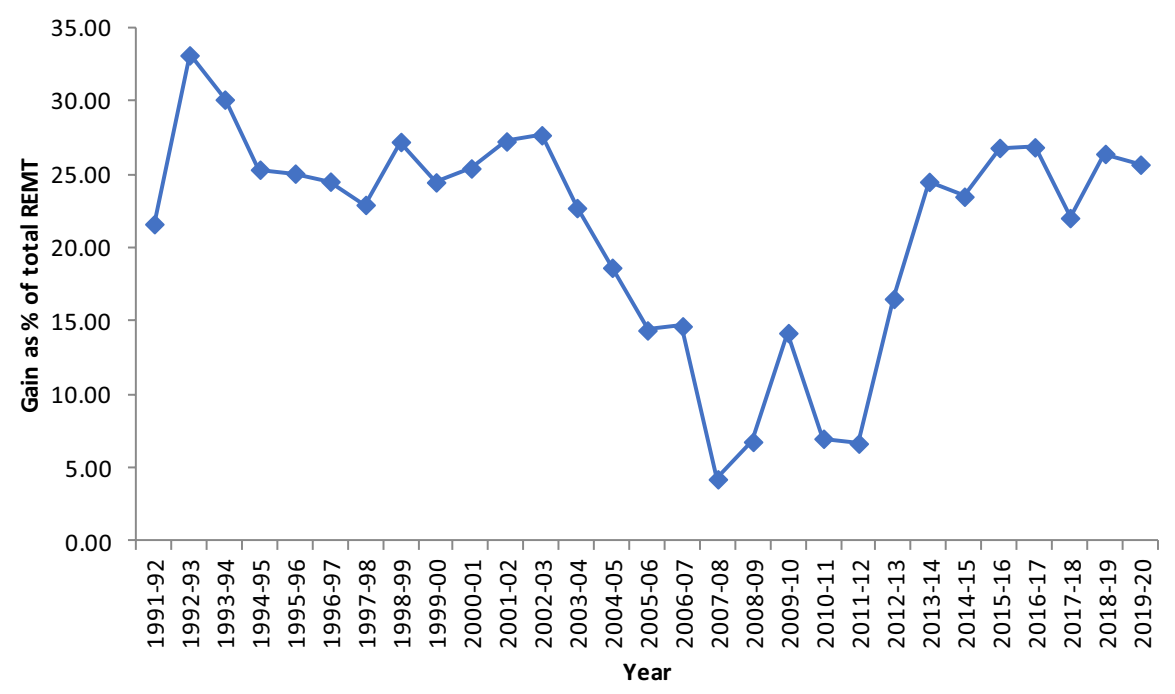

Fig. 3 Windfall gain in remittances (REMT) post-liberalisation. Source: Authors' estimate

where $G_{r t}=$ gain in rupees as a result of exchange rate liberalisation, $R_{t}=$ actual remittance in US dollars, $r_{a t}=$ actual exchange rate, $r_{e t}=$ expected exchange rate and $t=$ time point.

The expected exchange rate was calculated by projecting the growth rates under the fixed exchange rate system that the Government of India followed including our remittance period 1973 to 1990 . Since the exchange rate liberalisation in 1991, Kerala has gained a 'windfall' that works out to Rs. 2,35,676 crores in Indian rupee (in nominal terms) for a period covering 29 years since 1990-1991. This comes to an annual average of Rs. 4910 crores. As a percentage equivalent of NSDP, this works out to $3.6 \%$ for the 29 -year period combined. Taken as an average annual flow for every 5-year period, the windfall gain increased from Rs. 1256.52 crores during 1991-1992 to 1995-1996 to Rs. 17,258.89 crores during 2011-2012 to 2015-2016 and then to Rs. 22,922.24 crores per annum for the last 4 years. Expressed as a percentage of total remittances that conveys a more meaningful measure of the relative gain, the gain works out to more than 20\% except for a decade from 2003 to 2004 (Fig. 3).

\subsection{Impact on Income, Consumption and Savings}

The macroeconomic impact of the remittances on the regional economy was evaluated by estimating the impact of the remittances on income, consumption and savings. As mentioned in the beginning, a modified NSDP, called Modified State Income (MSI), for Kerala was estimated by adding the series of total remittances with the NSDP. This shows that the per capita income in Kerala, when the annual flow of direct remittance is added, is significantly higher than the reported official per capita income. Until 1990, it was less than $14 \%$ but rose to $20-25 \%$ between 


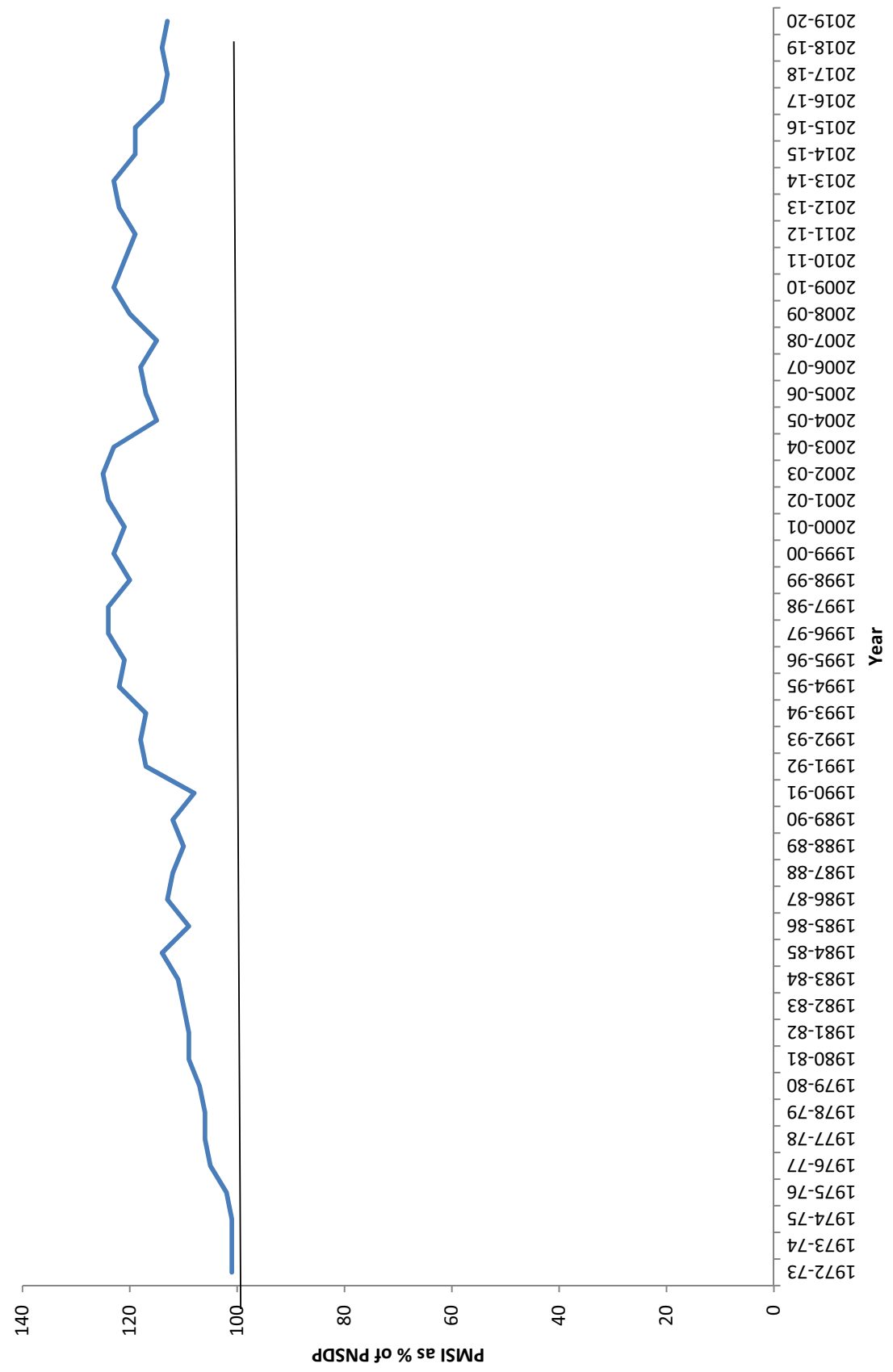

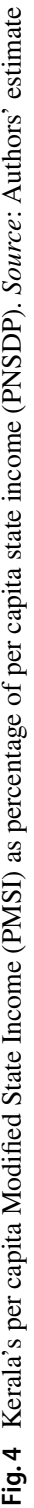


Table 5 Average propensity to consume (APC) and save (APS) in Kerala

\begin{tabular}{lrlll}
\hline Years & APCE & $\begin{array}{l}\text { APC out of } \\
\text { PNSDP }\end{array}$ & $\begin{array}{l}\text { APC out of } \\
\text { PMSI }\end{array}$ & $\begin{array}{l}\text { APS out } \\
\text { of PMSI }\end{array}$ \\
\hline 1 & 2 & 3 & 4 & 5 \\
$1972-1973$ & 534 & 0.81 & 0.80 & 0.20 \\
$1977-1978$ & 903 & 0.87 & 0.81 & 0.19 \\
$1983-1984$ & 1795 & 0.86 & 0.77 & 0.23 \\
$1987-1988$ & 2647 & 0.90 & 0.81 & 0.19 \\
$1993-1994$ & 4982 & 0.64 & 0.55 & 0.45 \\
$1999-2000$ & 9959 & 0.51 & 0.42 & 0.58 \\
$2004-2005$ & 13,306 & 0.41 & 0.36 & 0.64 \\
$2009-2010$ & 26,620 & 0.43 & 0.35 & 0.65 \\
$2011-2012$ & 33,765 & 0.34 & 0.29 & 0.71 \\
\hline
\end{tabular}

Source: Per capita annual consumer expenditure data from the Employment and Unemployment Rounds of the NSS for the years indicated in column 1. Source of data for NSDP as mentioned in Table 1

1995 and 2004. Since 2016 to 2020, it is around 13-14\% (Fig. 4). This MSI is, however, not a substitute for calculating the net income of a regional economy by factoring 'net payments from abroad' as in the case of calculating the gross or net national product of a country. ${ }^{7}$

Remittances to the Kerala economy started assuming significance from the early 1980s when it was equivalent to $10 \%$ of the NSDP. We have seen (Table 1) how it reached an equivalence of $21-22 \%$ on an average during the quarter century beginning with the early 1990s. Since 2014, it started declining as a percentage of the NSDP and currently stands at $13 \%$. Once again, we must caution that the share for the 1980s might be an underestimation due to the administered exchange rate system and the consequent incentive for sending remittances through illegal channels. If this argument is a plausible one, then the share of remittances in the NSDP during the 1980s might have been higher than what is reported in Table 1.

We have also worked out the relationship between the per capita consumption, per capita NSDP and MSI through the estimation of the average propensity to consume out of NSDP and MSI. The results are given in Table 5. The propensity to consume remained well above $80 \%$ of the MSI and $85 \%$ of the NSDP till the early 1990s. Given an increasing trend in income, the average propensity to consume has declined to half of the per capita NSDP (PSDP) and less than half of the per capita MSI (PMSI). It reached as low as 34 and 29\% out of the NSDP and MSI, respectively, by 2011-2012. Since then, the only detailed consumer expenditure

\footnotetext{
7 For calculating the net annual income of a regional economy, we should have data on the value of all export earnings including merchandise, service payments and net private transfers. The money spent on all imports including merchandise, services and payments to migrant workers should then be deducted to obtain the 'net payments from abroad'. Strictly speaking, such an exercise should treat all incomes and payments from and to the rest of the country as well as abroad.
} 
Table 6 Per capita state income (PNSDP), per capita Modified State Income (PMSI) and average per capita consumer expenditure (APCE) in Kerala (K) as percentage of all India (I)

Table 7 Relative magnitude of remittances to Kerala

\begin{tabular}{llll}
\hline Years & $\begin{array}{l}\text { PNSDP (K) as \% } \\
\text { of PNDP (I) }\end{array}$ & $\begin{array}{l}\text { PMSI (K as \% } \\
\text { of PNNP (I) }\end{array}$ & $\begin{array}{l}\text { APCE (K) as } \\
\% \text { of APCE (I) }\end{array}$ \\
\hline $1972-1973$ & 82 & 83 & 93 \\
$1977-1978$ & 77 & 83 & 101 \\
$1983-1984$ & 85 & 95 & 120 \\
$1987-1988$ & 82 & 95 & 122 \\
$1993-1994$ & 99 & 119 & 127 \\
$1999-2000$ & 120 & 149 & 141 \\
$2004-2005$ & 124 & 143 & 158 \\
$2009-2010$ & 129 & 159 & 186 \\
$2011-2012$ & 154 & 184 & 172 \\
\hline
\end{tabular}

Source: Authors' estimate

\begin{tabular}{llrlcc}
\hline Years & \multicolumn{5}{l}{ Remittances as \% of } \\
\cline { 2 - 6 } & NSDP & \multicolumn{1}{c}{ GE } & VA (M) & VA (I) & VA (A) \\
\hline $1989-1990$ & 12 & 47 & 70 & 42 & 33 \\
$1999-2000$ & 23 & 113 & 208 & 110 & 105 \\
$2009-2010$ & 23 & 134 & 344 & 110 & 170 \\
$2014-2015$ & 19 & 110 & 239 & 94 & 177 \\
$2019-2020$ & 13 & 70 & 149 & 61 & 164 \\
\hline
\end{tabular}

GE, government expenditure; VA (M), value added in manufacture; VA (I), value added in industry; VA (A), value added in agriculture. Source: Basic figures for remittances taken from Table 1. Data for other variables from Government of Kerala, Economic Review, various issues

survey carried out by the National Sample Survey Organization in 2017-2018 was not released by the Government of India. ${ }^{8}$ By deducting the APC from per capita income (PNSDP and PMSI), we have also reported the average propensity to save (APS) that shows a high rate of gross savings in Kerala. However, we must point out here that there has been a controversy over the disparity in consumer expenditure as reported through household surveys of NSS and that estimated in the National Accounts Statistics (NAS). ${ }^{9}$ Even if we modify the APC based on NSS by a certain margin say, $30 \%$, due to the underrepresentation of very-high-income groups in the sample, the APS of Kerala shows a very high rate of saving.

\footnotetext{
$\overline{8}$ A media report that secured a copy of the report on consumer expenditure reported in decline in the per capita consumption expenditure in the country and that could have motivated the government to withhold and later reject the report (see Jha 2019).

9 Scholars such as Sundaram and Tendulkar (2003) have examined the differences between NSS and NAS consumption data in great detail and came to the conclusion that NSS data are preferable 'because they are based on direct observations relating to the survey period and because, unlike NAS, they avoid recourse to adjustments based on arbitrary assumptions'.
} 
Table 8 Growth rates in remittances and selected key variables for Kerala

\begin{tabular}{lcccc}
\hline Variable & $\begin{array}{l}1980-1981 \\
\text { to } 1989-\end{array}$ & $\begin{array}{l}1991-1992 \\
\text { to 2010- } \\
\text { 1990 }\end{array}$ & $\begin{array}{l}\text { 2011 } 2012 \\
\text { to 2019- } \\
2020\end{array}$ & Whole period \\
\hline 1. Remittances (US\$) & 6.78 & 9.47 & 1.52 & 10.75 \\
2. Remittances (in rupees) & 13.19 & 14.96 & 3.38 & 15.66 \\
3. Per capita (population) remittance (Rs) & 11.77 & 12.78 & 2.88 & 14.91 \\
4. Remittance per emigrant (Rs) & -3.90 & 6.82 & 4.70 & 8.17 \\
5. Remittance per emigrant (US\$) & -10.36 & 4.56 & 5.46 & 3.23 \\
6. Remittance per receiving households & -2.99 & 10.25 & 4.84 & 9.89 \\
7. NSDP (current prices) & 11.32 & 12.48 & 10.13 & 14.25 \\
8. MSI (current prices) & 11.50 & 13.45 & 10.90 & 14.43 \\
9. Per capita NSDP (current prices) & 9.91 & 12.63 & 10.06 & 13.30 \\
10. Per capita MSI (current prices) & 10.09 & 11.65 & 10.36 & 13.66 \\
11. Per capita consumption expenditure* & 9.41 & 9.95 & & \\
12. Total bank deposit** & 15.98 & 14.31 & 13.19 & 14.69 \\
(a) Domestic bank deposit & 13.55 & 15.18 & 10.34 & 14.25 \\
(b) NRE deposit & 24.66 & 12.52 & 18.98 & 15.85 \\
\hline
\end{tabular}

We have omitted the year 1990-1991 in the growth rate calculations in Table 9 since that year witnessed a sudden decline in remittances due to the Iraq war. *The period 2011-2012 to 2019-2020 could not be calculated since the data for 2017-2018 were not released by the Government of India. For the earlier periods, the time series for per capita consumption was generated through interpolation based on the data for the different rounds as indicated in the years in Table 6. **Only commercial bank deposits. Kerala has a vibrant cooperative banking sector, but time-series data for our periods were hard to obtain

The savings rate in the Kerala economy seems to have increased tremendously since the early 1990s. What is not consumed is savings, and these are held as either financial or non-financial assets. In the Kerala context, much of the savings have gone into house construction, investment in gold and in financial assets.

An indirect test of reliability of our estimates of remittances and consequently of Modified State Income (MSI) is possible by examining the trend in per capita consumer expenditure and income in Kerala relative to all India. The relevant figures are given in Table 6. The annual average per capita consumer expenditure (APCE) in Kerala was below the national average till 1977-1978. But the per capita NSDP matched that of all India only in 1999-2000. But when we take the MSI that includes the annual remittances, the per capita MSI matched with that of all India by 1993-1994. This mismatch is perhaps due to the illegal remittances until the liberalisation of the foreign exchange rate of the rupee. Since the turn of the twenty-first century, it is the PMSI that matches more with the per capita consumption (APCE) for Kerala than the PNSDP suggesting the role of remittances in filling the gap between consumption and state income (NSDP) in Kerala. 


\subsection{Relative Magnitude of Remittances}

There is no doubt that by the 1990s, remittance income has emerged as a major macroeconomic variable in the Kerala economy. The relevant figures are given in Table 7. By the early 1990s, remittances reached $12 \%$ in equivalence to the state income but considerably less than the total government expenditure or value added in agriculture or industry. The situation changed dramatically by the end of $1990 \mathrm{~s}$ when remittances equalled $23 \%$ of the state income and exceeded the total government expenditure as well as the value added in agriculture and industry. By 2010, the gap widened while the relative size of remittances remained constant. What is interesting is that since 2011, the importance of remittance has started declining as a percentage of NSDP, government expenditure and value added in industry. However, it continues to be much higher than the value added in manufacturing by $49 \%$ that shows the catching-up process by the manufacturing sector in Kerala. A small part of it could be due to the change in methodology of estimation of national income in India by changing to a new base to 2011-2012 (that affects the computation of state income as well). ${ }^{10}$ However, as shown in Table 8 , the growth rate in remittances decelerated to $3.88 \%$ since $2011-2012$, while the state income continued to grow over $10 \%$ in nominal terms. This declining share of remittances in relation to crucial macroeconomic variables in Kerala needs some elaboration and perhaps shows the signs of a new phase of growth in the Kerala economy. We comment on this in the last section.

Apart from the monetary value of remittances and its contribution to the Kerala economy, another important dimension of emigration is the impact on Kerala's labour market. Since $90 \%$ of emigrants were reported to be in employment, working emigrants constituted 7\% of Kerala's workforce within the state in 1993-1994 that almost doubled to $13.7 \%$ in 2004-2005. By 2011-2012, it increased to $16.5 \%$ and to $17.3 \%$ in $2017-2018 .{ }^{11}$ It is interesting to note that by $2017-2018$, the total number of working emigrants is close to total employment in Kerala's organised or formal sector estimated at 20.1 million.

\subsection{Dynamics of Remittance in relation to Income, Consumption and Bank Deposits}

The relative importance of remittances can also be represented in dynamic terms to show the importance of remittance to the economy (Table 8). As in previous tables, all calculations are in current prices. Between 1980 and 2012, the annual growth in remittances was greater than the growth in NSDP as well as MSI and this is also

\footnotetext{
${ }^{10}$ In 2011-2012, the NSDP for Kerala increased by 40\% compared to the previous year. A major part of this seems to be due to the change in methodology of estimation of national income.

11 Kerala's workforce that is the denominator here has been declining in absolute terms since 2004-2005 from 130.4 lakhs in that year to 127 lakhs in 2011-2012 and then to 110.7 lakhs in 2017-2018. Given high economic growth during this period, the negative growth in workforce tells a story of joblessrather jobloss-growth in the Kerala economy.
} 
Table 9 Inequality in per capita Modified State Income (PMSI) as between remittance-receiving and not-receiving population in Kerala (in Rs. current prices)

\begin{tabular}{llll}
\hline Years & $\begin{array}{l}\text { A. Remittance- } \\
\text { receiving population }\end{array}$ & $\begin{array}{l}\text { B. Population } \\
\text { without remit- } \\
\text { tances }\end{array}$ & Ratio A/B \\
& $\begin{array}{l}\text { PMSI } \\
\text { (PNSDP + PREMT) }\end{array}$ & PMSI (=PNSDP) & \\
\hline $1993-1994$ & 18,693 & 9129 & 2.05 \\
$2004-2005$ & 64,687 & 32,140 & 2.01 \\
$2011-2012$ & 197,008 & 97,911 & 2.01 \\
$2019-2020$ & 402,659 & 226,452 & 1.78 \\
\hline
\end{tabular}

PNSDP, per capital state income; PREMT, per capita remittances; PMSI $=$ PNSDP plus PREMT

Table 10 Percentage distribution of international remittances received by households by consumption decile group in Kerala, 2007-2008

\begin{tabular}{llllllllllll}
\hline Decile group & 1 & 2 & 3 & 4 & 5 & 6 & 7 & 8 & 9 & 10 & Total \\
\hline H-REMT (\%) & 4.43 & 4.23 & 4.71 & 5.13 & 8.47 & 9.94 & 7.52 & 15.13 & 16.20 & 24.25 & 100.00 \\
NRI-D (\%) & 0.00 & 0.00 & 0.00 & 0.00 & 0.00 & 13.60 & 10.30 & 20.72 & 22.18 & 33.21 & 100.00 \\
\hline
\end{tabular}

Columns 2, 3 and 5 are based on unit-level data of NSSO 64th Round on Employment, Unemployment and Migration in India (2007-2008). NRI-D stands for deposits by non-resident Indians in Indian banks distributed to consumption decile groups

reflected in the per capita growth in these variables. This has also contributed to maintaining a high growth in consumption. Growth in total outstanding bank deposits was marginally higher perhaps reflecting the multiplier effects of remittance in the economy. What is significant to note is the continuing resilience in growth in NSDP and MSI as well as bank deposits despite a steep decline in the rate of growth in remittances. The higher growth rate in NRE deposits during 2011-2012 and 2019-2020 seems to be a sign of higher per capita per emigrant earnings leading to a higher rate of saving.

\subsection{Some Larger Issues Arising Out of a Remittance-Driven Economy}

As a result of the high growth rate of the economy assisted by international remittances and an early demographic transition, Kerala's per capita income surpassed all India. In an international perspective, Kerala's per capita income at the turn of this century (2000-2001) was US\$447 and US\$539 as measured by NSDP and MSI, respectively. Two decades later (2019-2020), they stood at US $\$ 3194$ and US $\$ 3620$, respectively. For all India, the per capita net domestic product (NDP) in these two time points was US\$ 416 and US\$ 1906, respectively. If Kerala is to be treated as a country, its status is now close to the definition of a 'middle-income country' (US\$3996 to US\$12,375). However, this achievement, while impressive in the South Asian context, is not as impressive as some of the South East Asian economies 
Table 11 Gini ratios of income inequality for Kerala
Table 12 Unemployment rates by educational level
Inequality based on the 1993-1994 2004-2005 2011-2012 distribution of

\begin{tabular}{llll}
\hline 1. Kerala (based on CE) & 0.32 & 0.39 & 0.44 \\
2. India (based on CE) & 0.31 & 0.34 & 0.38 \\
3. NSDP & 0.30 & 0.37 & 0.42 \\
4. MSI (1) & 0.32 & 0.38 & 0.42 \\
5. MSI (2) & 0.33 & 0.38 & 0.43
\end{tabular}

CE stands for consumption expenditure. 1 and 2 are based on the decile-wise distribution of consumption expenditure. 3 is based on state income by taking the distribution as in 1.4 is based on Modified State Income (NSDP plus remittances). 5 is based on NSDP based on consumption distribution and remittance distribution based on consumption decile-wise distribution as obtained from the NSSO 64th Round and given in Table 11

\begin{tabular}{llllll}
\hline Years & \multicolumn{2}{l}{ Below secondary } & & \multicolumn{2}{l}{ Secondary \& above } \\
\cline { 2 - 3 } \cline { 6 - 7 } & Men & Women & & Men & Women \\
\hline $1993-1994$ & $3.0(1.1)$ & $4.4(0.5)$ & & $14.0(6.3)$ & $33.2(17.4)$ \\
$2011-2012$ & $1.1(1.4)$ & $6.7(1.0)$ & & $5.6(3.7)$ & $22.1(9.8)$ \\
$2017-2018$ & $1.6(3.8)$ & $3.4(1.1)$ & & $11.0(9.9)$ & $35.6(18.5)$ \\
\hline
\end{tabular}

Figures in brackets refer to all India. Source: Computed from unitlevel data from the 50th and 68th Rounds of NSS and PLFS 20172018 (see Kannan and Raveendran 2020: 117)

such as Indonesia (US\$4193), Thailand (US\$6502) or Malaysia (US\$12,478) but well above Vietnam (US\$2715) with a comparable human development ranking. But given its commendable achievement in reducing multidimensional poverty and enhanced human development, Kerala presents itself well in a developmentalist perspective. For example, the most recent estimate of Multidimensional Poverty for Indian States (see OPHI 2020) shows Kerala at the top with $1.1 \%$ of the population as multidimensionally poor as against $27.9 \%$ for India. It also compares well with such countries as Thailand $(0.8 \%)$ and better than Indonesia $(3.6 \%)$ and Vietnam (4.9\%). In fact, Kerala's performance is one of the best among all global regions and close to Europe and Central Asian average (1.0\%) (see UNDP and OPHI 2020: 41).

However, despite the significance of remittances in powering and transforming the Kerala economy, there are some crucial issues that should worry both the state and the society. A brief comment is made here on three such problem areas.

(i) Increasing Income Inequality: Remittances constitute 'outside money' in the case of a regional economy like Kerala that is not counted in the official estimate of annual income (NSDP). It is entirely a private transfer because it is the households that are the recipients of this outside money. When such a private transfer takes place only to a small segment of the total households, it creates inequality in income 
as between those households (and population) receiving remittances and those who do not. These are shown as per capita income in Table 9 for three time points.

These are statistical averages and do not reveal the distribution of income. To understand inequality, we need to know the distribution of the income. In India, this is usually carried out on the basis of consumption expenditure data. We have taken the distribution of consumption expenditure data and applied it to the NSDP. However, there is a problem in distributing the remittances as per the distribution of NSDP because only a segment of the households reported emigration. Fortunately, the 64th Round of NSS included information on remittances receiving households as well as the remittances (in Rs) received. We have applied this distribution of remittances for the three selected years to compute the income inequality based on MSI (Table 10). The results (as Gini ratios) are given in Table 11. However, this distribution takes into account only those remittances that are homebound. The NRE remittances through bank deposits are not reflected here. Here, we make some assumptions on distribution of NRE-type remittances in the sense that emigrants belonging to poorer and lower middle classes are unlikely to have any significant NRE deposits say the first five consumption deciles from the bottom. Therefore, the NRE remittances are distributed to the top five deciles in the same proportion as home-bound remittances. The resultant inequality ratios are also reported in Table 11. An interesting insight from the 64th Round of the NSS is that close to $19 \%$ of the remittances accrue to households belonging to the four deciles from the bottom. That is to say, direct remittances to the poorer houses might have eased their poverty to some extent.

Our results on inequality show that Kerala has gone through a period of rapid growth in inequality in income since the onset of economic reforms. And this has been exacerbated by the unequal distribution of emigration and the resultant remittance income to the households. However, we must keep in mind that inequality (expressed as Gini ratio) for the selected years is influenced by the impact of remittances during the previous years through consumption and investment multipliers. If our assumption on the distribution of NRE deposit is a reasonable one, then the inequality due to the total remittance income gets further skewed in favour of the richer classes in the society. This constitutes a further challenge to Kerala's development trajectory given its earlier record of social justice and human development to the less fortunate members of the society.

(ii) High Educated Unemployment: There is no doubt that the uninterrupted and increasing remittances, in both absolute and relative terms, were a factor in pulling Kerala out of its stagnant growth bootstraps. Ever since the turnaround in growth in 1987-1988, Kerala economy has been on a high growth path. The sustainability of this high growth path was the result of a historic conjunction in the form of initial investment in human and social development that enabled the large-scale emigration of people in search of jobs resulting in sizeable remittances, and a specific national economic policy reform in liberalising the foreign exchange rate of the Indian rupee. Despite the impressive success in the growth front, there has not been a reasonable resolution of the problem of educated unemployment. The situation for the last quarter century is summarised in Table 12. With increasing levels of education and falling incidence of poverty, there has been a steady withdrawal of 


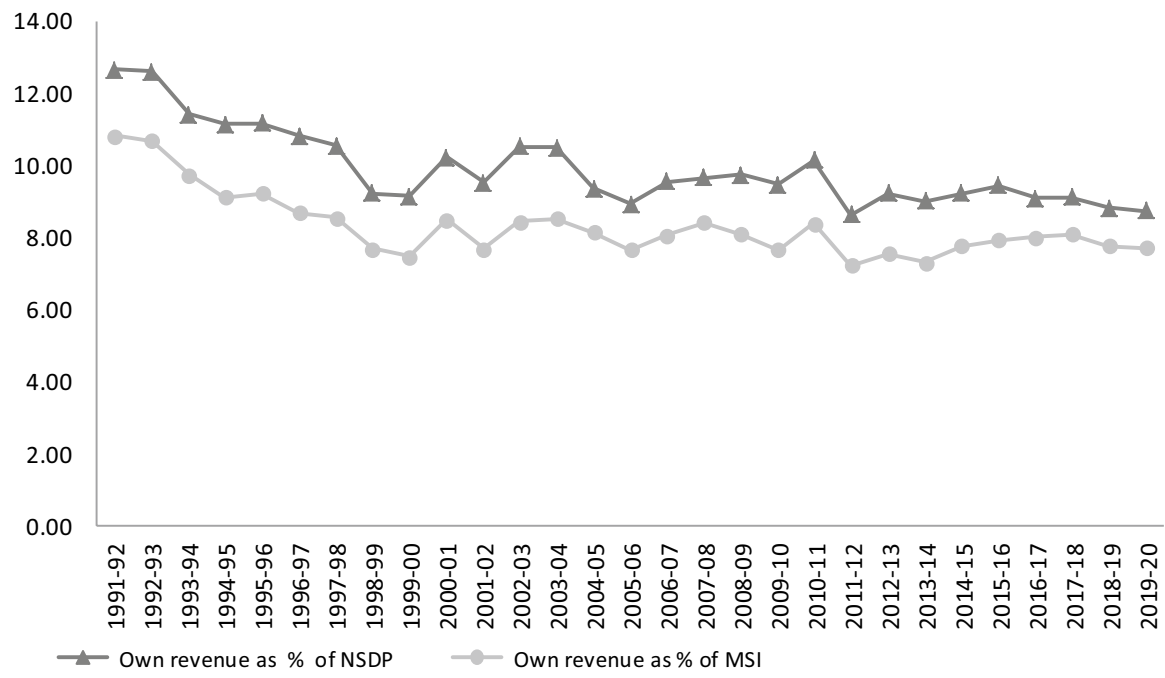

Fig. 5 Kerala's own revenue as percentage of NSDP and MSI Source: Computed from data given in Reserve Bank of India, State Finances: A Study of Budgets, various issues; and Central Statistical Organisation, Estimates of State Domestic Product of India, various issues

both men and women from much of manual work (most visibly in agriculture and construction) that led to an increase in wages for casual work. This has effectively resolved the problem of 'less educated unemployment' for men and women. But the problem of 'educated unemployed' persisted. Given the steady increase in emigrants till 2011, educated unemployment for men declined significantly between 1993 and 2012 but resurfaced in 2017-2018 given the 'jobloss growth' in Kerala and all India during the latter period (see Kannan and Raveendran 2019, 2020). For women, the problem of 'educated unemployed' has been persistent at a very high level. Without the safety valve of national or international migration (except for a very small segment of specialised professionals such as nurses) and a continuing trend in acquiring higher educational levels, the educated unemployment rates among women have remained at unacceptably high levels. This is despite the withdrawal of a significant number of women from the labour force (see Kannan and Raveendran 2020). A similar picture of higher unemployment rate among men and women compared to the less educated is also seen at the all India level (Table 12), but the Kerala rates for women are double that of all India.

There is no doubt that the persistence of educated unemployment has been a central failure in Kerala's development experience characterised by an early demographic transition followed by a process of growth and structural transformation in both income and employment away from the primary sector.

(iii) Declining Tax Collection Efficiency: While aggregate economic growth increased, it was largely, if not only, first led by construction (part of the secondary sector) followed by the service sector (see Pushpangadan 2003). What is important to remember is that remittances are additional income accruing to the household 
Table 13 Share of remittance to India

\begin{tabular}{lll}
\hline Years & $\begin{array}{l}\text { Sterling area: Persian } \\
\text { Gulf }\end{array}$ & $\begin{array}{l}\text { Non-sterling area: W } \\
\text { Asia and N Africa }\end{array}$ \\
\hline $1973-1974$ & 10 & - \\
$1974-1975$ & 20 & 50 \\
$1975-1976$ & 50 & 50 \\
$1976-1985$ & 66 & 90 \\
$1985-1991$ & 66 & 80 \\
$1991-2000$ & $66^{*}$ & 80 \\
\hline
\end{tabular}

From the point of remittance, the important Persian Gulf countries in the sterling area are Bahrain, Kuwait, Oman, Qatar and UAE. For West Asia and North Africa, the countries of importance are Saudi Arabia, Iran, Iraq and Libya. For details on the assumptions, see Nayyar (1994). *We assume the same share for 1991-2000 as in the previous period suggested by Nayyar

economy and that the state government's benefit in terms of additional income is through tax revenue on consumption of goods and services. We do not have evidence to suggest that the Kerala government has been efficient enough in this respect. For example, the tax-to-state income ratio shows a declining trend (Fig. 5) in terms of NSDP as well as MSI. Since it is the MSI that constitutes the basis for consumption, it is this ratio that is of relevance. This ratio comes down by 1.5 to $2.0 \%$ points when compared to the NSDP-based ratio although a narrowing down to a little more than $1 \%$ is visible for the last 4 years. What should be more worrying for the government, from a public finance point of view, is the declining trend in tax collection efficiency whether measured by NSDP or MSI.

\subsection{Concluding Remarks}

\subsubsection{Implications of the Relative Decline of Remittances}

Since 2011-2012 to the present, the growth rate in remittances declined considerably to as low as $3.4 \%$ per annum, but the economy continued to register a growth rate of over $10 \%$ in nominal terms (Table 8). What this means is that the earlier flow of remittances helped the Kerala economy to grow faster than otherwise. And that raised the state income that constitutes the new denominator to calculate the equivalence of subsequent remittances to the state income. In sum, a stage has now reached such that the Kerala economy seems to have picked up enough resilience even as it enters a phase of a relative decline in remittances. However, the positive gain in the form of a higher-income base of the Kerala economy (along with other positive gains such as enhanced educational and health standards, especially of the younger population) could prove to be inadequate and even lead to a crisis, if the sharp decline in economic activity arising out of the COVID-19 pandemic that started in March 2020 continues for the rest of the year. That, of course, will be part of a generalised crisis in India as well as the rest of the world. It could spell a turning point in terms of a sharp phase down in Kerala's large-scale labour migration to the Gulf 
Table 14 Stock of emigrant population from India in Gulf countries (figures in lakhs)

\begin{tabular}{llllllll}
\hline Years & 1975 & 1976 & 1979 & 1981 & 1983 & 1987 & 1991 \\
Stock of India & $2.66^{1}$ & $2.05^{2}$ & $5.01^{3}$ & $5.99^{4}$ & $9.16^{5}$ & $9.57^{6}$ & $16.5^{7}$
\end{tabular}

NA, not available. Source: ${ }^{1}$ Birks and Sinclair (1981); ${ }^{2}$ Serageldin et al. (1981); ${ }^{3,4,5,6,7}$ Government of India. Ministry of Labour, Annual Report, various issues

countries. Alternatively, it could set off a beginning of a change in the composition of emigration if the demand for healthcare personnel increases in the Gulf as well as in other countries. In these uncertain times, Kerala economy as well as society and polity will be facing unprecedented challenges further complicated by the environmental disasters such as floods (already experienced in 2018 and 2019). It could well be an opportunity to chart a new developmental path within a framework of environmental sustainability and employment creation, especially for the educated adults. The national context on these objectives is certainly not an enabling one, let alone an encouraging one, despite rhetorical declarations, to put it modestly. But the big question here is the ability of Kerala's polity to provide the required visionary political leadership.

Acknowledgement We would like to place on record our thanks to K.C. Zachariah and S.L. Shetty for their comments on an earlier version of the paper and to Jan Breman, Gerry Rodgers, D. Narasimha Reddy, J. Krishnamurty and K. Pushpangadan for their comments and views on the current version. The authors alone are responsible for errors, if any.

\section{Appendix}

For estimating remittances to the Kerala economy, we have computed the following: (i) the share of Kerala in the net private transfers (NPTs) in the current account of the balance of payments of India, (ii) the non-resident Indian (NRI) deposits in banks located in Kerala and (iii) the money equivalent of remittance in kind.

Computation of Net Private Transfers: Data relating to net private transfers to India are available according to currency areas (such as sterling area, dollar area, OECD area and rest of non-sterling area), but not according to countries or geographic regions such as the Middle East till 2005. However, it is well known that an overwhelming share of Kerala emigrants is in the Middle East countries. Therefore, the first task is to estimate the NPT to India from Middle East countries and all other countries. Based on the distribution of Indians abroad, Nayyar (1994) made certain assumptions for calculating the share of remittances to India from the Middle East countries. They are given in Table 13.

For the period 2000-2001 to 2005-2006, there was a modification in the data presentation of the Reserve Bank of India (RBI) in its reporting of private transfers 
region wise. The continent-wise data as well as the aggregate private transfers to India are presented in RBI's Currency and Finance Report 2003 and 2006. Here, the share of Middle East countries was worked out from Asia's share in total remittances to India for period 1997-1998 to 2005-2006. Net private transfers from Middle East towards India are estimated by assuming share of Middle East in Asia to be $75 \% .{ }^{12}$ Actual figures for net private transfers from Middle East are available in RBI Annual Report (2010) for period 2006-2007 to 2008-2009. From 2010 onwards, World Bank remittance matrix database provides detailed country-wise remittance data into India. We have corroborated the remittance data of World Bank with that of RBI balance of payment data and used the World Bank data since it gives country-wise disaggregated figures on remittance flow.

Having estimated the share of NPT to India from Middle East and other regions, respectively, the next task is to estimate a share for Kerala from these two regions. For Middle East, we estimated the share of persons from Kerala in the stock of Indians in Gulf countries. This share was applied to the remittances from Middle East countries.

The share of Keralites in Gulf countries was estimated as follows. First, we have the data on stock of Indians for some time points as given in Table 14 for the period up to 1972-1973 till 1999-2000. Using the information, we have constructed timeseries data by interpolation and extrapolation. The share of Kerala in the total stock of Indians in Gulf countries has been applied to the total NPT to India from Middle East countries to obtain Kerala's share in NPT.

For Kerala, we have been able to obtain the actual stock of Kerala emigrants for the period 1980 to 1998 in Gulf countries from the data of 1998 study of Zachariah et al. (2001). These relate to (a) number of emigrants in 1998 by year of emigration, (b) number of return emigrants by year of return and (c) the number of return emigrants by year of emigration. The sum of the cumulative total of emigrants under (a) and the year-wise figures of (c) will give the stock of Keralites in the Gulf countries in a given year. For the period 1972-1979, we have estimated the stock of Keralites, by interpolation with the condition that the figures for 1980 should match the actual figures. For 1999-2000 till 2003-2004, we have interpolated the stock of emigrants based on KMS 2004 (Zachariah and Irudaya Rajan 2004).

Country-wise data for Kerala emigrants are available in KMS for years 1998, 2003, 2008, 2011, 2014 and 2018 (Zachariah and Irudaya Rajan 2004, 2010, 2015, and Irudaya Rajan and Zachariah 2019).

Country-wise data for Indian emigrants are available in UN Population Database provided by Population Division, Department of Economic and Social Affairs of United Nations. These data are available for years 2000, 2005, 2010 and 2015. For the period 2013 and 2017, World Bank also gives bilateral migration matrix. We have corroborated the stock of emigrants from India in different countries from various sources and found only marginal differences across the sources. Intermediary year figures were extrapolated using logarithmic growth

\footnotetext{
12 This assumption is validated by the fact that in 2010 remittance data by World Bank, the share of remittances from Middle East in total remittances from Asia towards India is approximately $75 \%$.
} 
Table 15 Estimated stock of Indian and Kerala emigrants (lakhs)

\begin{tabular}{|c|c|c|c|c|}
\hline Years & $\begin{array}{l}\text { Indian } \\
\text { emigrants in } \\
\text { Gulf }\end{array}$ & $\begin{array}{l}\text { Kerala } \\
\text { emigrants in } \\
\text { Gulf }\end{array}$ & $\begin{array}{l}\text { Kerala as } \\
\% \text { of India }\end{array}$ & $\begin{array}{l}\text { Kerala emigrants } \\
\text { in all countries }\end{array}$ \\
\hline 1973 & 1.95 & 0.34 & 17.44 & 0.34 \\
\hline 1974 & 2.27 & 0.39 & 17.18 & 0.39 \\
\hline 1975 & 3.05 & 0.44 & 14.43 & 0.45 \\
\hline 1976 & 3.49 & 0.51 & 14.61 & 0.51 \\
\hline 1977 & 3.99 & 0.58 & 14.54 & 0.59 \\
\hline 1978 & 4.57 & 0.67 & 14.66 & 0.67 \\
\hline 1979 & 5.23 & 0.76 & 14.53 & 0.77 \\
\hline 1980 & 5.99 & 0.79 & 13.19 & 0.80 \\
\hline 1981 & 5.99 & 0.98 & 16.36 & 0.98 \\
\hline 1982 & 7.41 & 1.52 & 20.51 & 1.60 \\
\hline 1983 & 9.17 & 1.83 & 19.96 & 1.94 \\
\hline 1984 & 9.30 & 2.01 & 21.61 & 2.03 \\
\hline 1985 & 9.31 & 2.42 & 25.99 & 2.58 \\
\hline 1986 & 9.45 & 2.76 & 29.21 & 2.84 \\
\hline 1987 & 9.58 & 3.05 & 31.84 & 3.05 \\
\hline 1988 & 10.98 & 3.82 & 34.79 & 4.04 \\
\hline 1989 & 12.60 & 4.02 & 31.90 & 4.24 \\
\hline 1990 & 14.45 & 5.09 & 35.22 & 5.30 \\
\hline 1991 & 16.57 & 5.4 & 32.59 & 5.68 \\
\hline 1992 & 18.58 & 6.45 & 34.71 & 6.63 \\
\hline 1993 & 20.83 & 7.44 & 35.72 & 7.65 \\
\hline 1994 & 23.35 & 8.6 & 36.83 & 8.80 \\
\hline 1995 & 26.18 & 9.63 & 36.78 & 9.95 \\
\hline 1996 & 29.35 & 10.97 & 37.38 & 11.26 \\
\hline 1997 & 32.90 & 12.36 & 37.57 & 12.80 \\
\hline 1998 & 36.88 & 12.78 & 34.65 & 13.62 \\
\hline 1999 & 33.74 & 13.43 & 39.80 & 14.53 \\
\hline 2000 & 27.43 & 14.11 & 51.44 & 15.30 \\
\hline 2001 & 29.15 & 14.82 & 50.86 & 16.25 \\
\hline 2002 & 30.98 & 15.58 & 50.28 & 17.27 \\
\hline 2003 & 32.92 & 16.36 & 49.72 & 18.38 \\
\hline 2004 & 34.98 & 16.93 & 48.41 & 19.05 \\
\hline 2005 & 37.17 & 17.52 & 47.14 & 19.73 \\
\hline 2006 & 41.50 & 18.13 & 43.69 & 20.44 \\
\hline 2007 & 46.33 & 18.76 & 40.50 & 21.17 \\
\hline 2008 & 51.72 & 19.41 & 37.54 & 21.93 \\
\hline 2009 & 57.74 & 19.73 & 34.17 & 22.22 \\
\hline 2010 & 64.46 & 20.05 & 31.11 & 22.51 \\
\hline 2011 & 67.62 & 20.38 & 30.14 & 22.81 \\
\hline 2012 & 70.93 & 20.49 & 28.89 & 23.18 \\
\hline 2013 & 74.40 & 20.71 & 27.83 & 24.00 \\
\hline 2014 & 78.04 & 20.53 & 26.31 & 23.32 \\
\hline
\end{tabular}


Table 15 (continued)

\begin{tabular}{lllll}
\hline Years & $\begin{array}{l}\text { Indian } \\
\text { emigrants in } \\
\text { Gulf }\end{array}$ & $\begin{array}{l}\text { Kerala } \\
\text { emigrants in } \\
\text { Gulf }\end{array}$ & $\begin{array}{l}\text { Kerala as } \\
\% \text { of India }\end{array}$ & $\begin{array}{l}\text { Kerala emigrants } \\
\text { in all countries }\end{array}$ \\
\hline 2015 & 81.86 & 20.35 & 24.87 & 22.72 \\
2016 & 84.19 & 19.87 & 23.60 & 22.21 \\
2017 & 86.59 & 19.40 & 22.40 & 21.71 \\
2018 & 89.06 & 18.94 & 21.26 & 21.22 \\
2019 & 89.06 & 18.94 & 21.26 & 21.22 \\
\hline
\end{tabular}

Source: Data sources as detailed in the text in the Appendix

rate additive technique using the KMS Data for 2003, 2008, 2011 and 2018. The figures for 2019-2020 are based on projected figures based on earlier trend. The proportion estimated is given in Table 15. In the same table, we also give the estimated stock of Keralites in all countries obtained in the same way.

Having thus obtained the share of NPT of Kerala, from Middle East, the next task is to find out Kerala's share in NPT from countries other than Middle East. For this, we applied a share of 5\% for the period 1972-1973 to 1990-1991. This is somewhat higher than Kerala's population share $(3.3 \%)$ to reflect the higher emigrating propensity of Keralites. For the subsequent period (i.e. 1991-1992 to 1999-2000), Kerala's share is taken at 8.5\%. This is obtained from the Kerala Migration Study conducted by Zachariah et al. (2000) wherein the source of remittances was obtained from the sample households. Post-2000 period, we have used the actual proportions based on subsequent KMS household surveys.

Computation of NRI Deposits in Banks in Kerala: Data relating to NRI deposits in banks located in Kerala are published in the annual Economic Review published by the State Planning Board, Government of Kerala. These deposits are of three types: FCNR (B) is repatriable deposits in foreign currency, NR(E)RA is repatriable deposits in Indian rupees and NR(NR)RD is in non-repatriable deposits in Indian rupees.

The net difference between each year's deposit and previous year's deposit stock has been taken as the net remittances through direct deposits to bank accounts. For the year 2019-2020, we have projected this number based on previous trend.

Computation of Remittances in Kind: The 1998 Kerala Migration Study (Zachariah et al. 2001) estimated the share of remittances in kind and this works out to $6.18 \%$ of total remittances. For the 1990 s, we have applied this share. For the period before 1990-1991, we have doubled this share to reflect the greater temptation to bring valuable electronic and other consumer durable goods. Subsequent surveys revealed that remittance in kind declined to $4.54 \%$ of total remittances in 2003 and $1.74 \%$ in 2007 . These proportions are assigned for the periods 2000-2001 to 2004-2005 and 2005-2006 to 2009-2010, respectively. From 2010 to 2011 , it has been taken as $1.5 \%$ since the trend in bringing commodities has decreased drastically (Irudaya Rajan and Zachariah 2019). 


\section{References}

Ahluwalia, Montek S. 2000. Economic Performance of States in Post-reform Period. Economic and Political Weekly 35 (19): 1637-1648.

Birks, J.S., and C.A. Sinclair. 1981. International Migration and the Development in the Arab Region. International Labour Office, Geneva, Working Paper No. 131.

Government of India, Ministry of Labour, Annual Report, 1979, 1981, 1983, 1987 and 1991.

Gulati, I.S., and Asoka Mody. 1983. Remittances of Indian Migrants to the Middle East: An Assessment with Special Reference to Migrants from Kerala. Centre for Development Studies, Working Paper No. 182.

Irudaya Rajan, S., and K.C. Zachariah. 2019. Emigration and Remittances: New Evidences from the Kerala Migration Survey 2018. Working Paper No. 483. Centre for Development Studies, Thiruvananthapuram.

Issac, Thomas T.M. 1997. Economic Consequences of Gulf Migration. In Kerala's Demographic Transition: Determinants and Consequences, ed. K.C. Zacheria and S. Irudaya Rajan. New Delhi: Sage Publications.

Jha. 2019. Consumer Spending Falls After 4 Decades. Business Standard, November 14.

Kannan, K.P. 1998. Political Economy of Labour and Development in Kerala. Economic and Political Weekly 33 (52): L61-L70.

Kannan, K.P. 2005. Kerala's Turnaround in Growth. Economic and Political Weekly 40 (6): 548-555.

Kannan, K.P. 2007. From Human Development to Economic Growth: Kerala's Turnaround in Growth Powered by Human Development, Remittances, and Reform. In Institutions and Markets in India's Development: Essays for K.N. Raj, ed. A. Vaidyanathan and K.L. Krishna. New Delhi: Oxford University Press.

Kannan, K.P., and G. Raveendran. 2019. From Jobless to Job-Loss Growth. Economic and Political Weekly 54 (44): 38-44.

Kannan, K.P., and G. Raveendran. 2020. India's Employment and Labour Market Dynamics. Study Carried Out for the ILO Decent Work Team South Asia Sub-regional Office, New Delhi (manuscript).

Kannan, K.P., and K.S. Hari. 2002. Emigration, Remittances and Their Macro Economic Impact. Centre for Development Studies, Thiruvananthapuram, Working Paper No. 328, March 2002.

Krishnan, T.N. 1994. Foreign Remittances, Consumption and Income. Thiruvananthapuram: AKG Centre for Research and Studies.

Nagaraj, R. 2019. Is India Overestimating Its Economic Growth? The Hindu, June 21.

Nair, Gopinathan P.R. 1989. Incidence, Impact and Implications of Migration to the Middle East from Kerala (India). In To the Gulf and Back: Studies on the Economic Impact of Asian Labour Migration, ed. R. Amjad. New Delhi: ILO/ARTEP.

Nayyar, Deepak. 1994. Migration, Remittances and Capital Flows: The Indian Experience. New Delhi: Oxford University Press.

OPHI (Oxford Poverty and Human Development Initiative). 2020. Global MPI Country Briefing 2020: India (South Asia). Retrieved from, http://ophi.org.uk/wp_content/uploads/CB_IND_2020.pdf. Accessed 17 July 2020.

Pushpangadan, K. 2003. Remittances, Consumption and Economic Growth in Kerala. Working Paper No. 343, Centre for Development Studies, Thiruvananthapuram.

Reserve Bank of India. 2001. Invisibles in India's Balance of Payments: 1997-1998 to 1999-2000. RBI Bulletin, January, pp. 20-37.

Reserve Bank of India. 2010. Invisibles in India's Balance of Payments: An Analysis of Trade in Services, Remittances and Income. Reserve Bank of India Bulletin, March, pp. 555-593.

Saith, Ashwani. 1992. Absorbing External Shocks, the Gulf Crisis: International Migration Linkages and the Indian Economy, 1990 (with Special Reference to Kerala). Development and Change 23: 101-146.

Serageldin, Ismail, et al. 1981. Manpower and International Labour Migration in the Middle East and North Africa. Washington, DC: World Bank.

Subramaniam, Arvind. 2019. India's GDP Mis-estimation: Likelihood, Magnitudes, Mechanisms, and Implications. CID Faculty Working Paper No. 354, Harvard University.

Subrahmanian, K.K. and Abdul Azeez. 2000. Industrial Growth in Kerala: Trends and Explanations. Working Paper No. 310, Centre for Development Studies, Thiruvananthapuram. 
Sundaram, K., and S. Tendulkar. 2003. NAS-NSS Estimates of Private Consumption for Poverty Estimation: A Further Comparative Examination. Economic and Political Weekly 38 (4): 376-384.

Sunny, Justin, Jajati K. Parida, and Mohammed Azurudeen. 2020. Remittances, Investment and New Emigration Trends in Kerala. Review of Development and Change 25 (1): 5-21.

UNDP and OPHI (United Nations Development Programme and Oxford Poverty and Human Development Initiative). 2020. Charting Pathways Out of Multidimensional Poverty: Achieving the SDGs. Retrieved from, http://hdr.undp.org/en/2020_MPI. Accessed 17 July 2020.

Zachariah, K.C., P.R. Gopinathan Nair, and S. Irudaya Rajan. 2001. Return Emigrants in Kerala: Rehabilitation Problems and Development Potential. Working Paper No. 319, Centre for Development Studies, Thiruvananthapuram.

Zachariah, K.C., and S. Irudaya Rajan. 2001. Migration Mosaic in Kerala: Trends and Determinants. Demography India 30 (1): 137-165.

Zachariah, K.C., and Irudaya Rajan. 2004. Gulf Revisited: Economic Consequences of Emigration from Kerala: Emigration and Unemployment. Working Paper 363, Centre for Development Studies, Thiruvananthapuram.

Zachariah, K.C., and Irudaya Rajan. 2010. Migration Monitoring Study, 2008: Emigration and Remittances in the Context of the Surge in Oil Prices. Working Paper No. 424, Centre for Development Studies, Thiruvananthapuram.

Zachariah, K.C., and Irudaya Rajan. 2015. Dynamics of Emigration and Remittances in Kerala: Results from the KMS 2014. Working Paper No. 463, Centre for Development Studies, Thiruvananthapuram.

Zachariah, K.C., E.T. Mathew, and Rajan S. Irudaya. 2003. Dynamics of Migration in Kerala: Dimensions, Determinants and Consequences. Hyderabad: Orient Longmans.

Zachariah, K.C., E.T. Mathew, and Irudaya Rajan. 2000. Socio-Economic and Demoigraphic Consequences of Migration in Kerala. Working Paper No. 303, Centre for Development Studies, Thiruvananthapuram.

Publisher's Note Springer Nature remains neutral with regard to jurisdictional claims in published maps and institutional affiliations. 